\title{
The Effect of Professional Sport Spectator's Experience Economy Factors on Satisfaction: Focused on Mediating Effects of Attachment and a Sense of Community
}

\author{
Hyuk-Jin LEE ${ }^{1}$, Sam-Kwon JUNG ${ }^{2}$, Myeong-Hee SEONG ${ }^{3}$ \\ Received: May 20, 2019 Revised: May 31, 2019 Accepted: July 13, 2019
}

\begin{abstract}
The purpose of this study is to investigate the relationship between the spectator experience and satisfaction with a focus on attachment and a sense of community. The survey was given to random spectators who watched KBO (The Korea Baseball Organization) games in 2018. With 189 surveyed participants, this study used exploratory factor analysis and reliability analysis to verify the reliability and validity of the measured variables. The hierarchical multiple regression correlation was employed as a statistical method for the hypotheses of this study. The findings showed that spectators' experiences have influences on satisfaction. Among the experience factors, education and entertainment affect attachment, and education has the only significant influence on a sense of community. In addition, spectators' attachment and a sense of community positively influence satisfaction. Attachment and a sense of community have a relatively mediated effect on spectators' experiences and satisfaction. This study confirmed the need for various spectator experiences at KBO games, and the importance of place attachment or a sense of community.
\end{abstract}

Keywords: Experience Economy, Attachment, A Sense of Community, Satisfaction, KBO(The Korea Baseball Organization).

JEL Classification Code: L83, M31, O18, Z20.

\section{Introduction}

The sports industry aims to produce goods and services related to sports, and is closely related to the local space and the sports distribution market. The professional sports industry has experienced rapid growth in a relatively short period when compared to other industries. This is because professional sports, as opposed to amateur sports, are sports in which athletes receive payment for their

1 First Author, Professor, Faculty of Liberal Arts, Eulji University, Korea. Email: hyuk2jin@eulji.ac.kr

2 Visiting Lecturer, Department of English and Global Business, Gimcheon University, Korea.

Email: jung3kwon@hotmail.com

3 Corresponding Author, Professor, Faculty of Liberal Arts, Eulji University, Korea.

Email: seong@eulji.ac.kr

๑ Copyright: Korean Distribution Science Association (KODISA)

This is an Open Access article distributed under the terms of the Creative Commons Atribution NonCommercial License (https://creativecommons.org/licenses/by-nc/4.0/) which permits unrestricted noncommercial use, distribution, and reproduction in any medium, provided the original work is properly cited. performance, and sports clubs and their sponsors attempt to earn profits. As mass media and increased leisure have brought more spectators, professional sports organizations or teams have earned a lot of income.

In Korea, professional baseball, professional soccer, professional basketball and professional volleyball form the four largest leagues. Among them, the Korean Baseball League is the most popular and is representative of the franchise regional tie-up system. The League was inaugurated in 1982 by the KBO (The Korea Baseball Organization), professional baseball's governing body in South Korea (Lee, 2006). The KBO League was founded with 6 franchises in 1982, and has expanded to 10 franchises.

The most unique feature of the $\mathrm{KBO}$ league is the existence of a local fan base that is corporate-owned. Like professional leagues in the United States where a professional team is located in a city or community, each $\mathrm{KBO}$ club is owned by a business which represents the hometown city as a franchise. Korea's professional sports are mostly located in large cities as a result of the larger 
retail market in cities. In the case of the $\mathrm{KBO}$, eight teams are located in Seoul and other metropolitan cities, while only two other teams are located in other cities.

The cities hosting KBO teams are seeking to enhance their community image and develop a regional focus on the sports distribution business from an economic perspective. For example, each team can make social contributions to enhance the spectators' attachment to the city and their sense of community. Also, efforts are made to promote the image of the parent company operating each team.

Global research related to professional sports has been intensively studied in the field of sports marketing. The majority of researchers have studied the physical environment of sports facilities, referred to as the sportscape, and they have examined the relationship between facility and attendance in the contexts of popular professional sports (Lambrecht, Kaefer, \& Ramenofsky, 2009; McEvoy, Nagel, DeSchriver, \& Brown, 2005; Shin \& Lyu, 2018). Several studies include important statements of the spectator's satisfaction for French ice hockey (Bodet \& Bernache-Assollant, 2011), for European professional football league (Biscaia, Correia, Rosado, Maroco, \& Ross, 2012; Theodorakis, Alexandris, Tsigilis, \& Karvounis, 2013) and for professional basketball (Moreno, Prado-Gascó, Hervas, Núñez-Pomar, \& Sanz, 2015).

In addition, as in the study on the relationships between service quality, customer satisfaction, and behavioral intention, several studies have sought direction on how to expand the spectator demand of the professional sports industry (Sutton, McDonald, \& Miline, 1997; Wang, Zhang, \& Tsuji, 2011). However, the studies of Korean professional sports have not been as in depth as those of overseas professional sports. The only studies found were Lee's (2006) exploratory study and Shin and Lyu's (2018) study on the physical environment of sports facilities.

This study was approached from the point of view of the representation of the KBO in the sports industry, the necessity of research on the spectator experience, and the importance for sports franchises in the age of glocalization. For research purposes, the scope of the study was limited to home fans at KBO games in 2018, and the survey was conducted at Suwon Stadium in Gyeonggi Province in Korea.

The study aimed to identify the relationships among the experience factors of attachment and feeling a sense of community. Also, the satisfaction of spectators watching their favorite teams was measured. In detail, the survey was conducted to examine the following research questions: 1) How many experience factors do the spectators have while watching a professional baseball game? 2) How do these experience factors affect satisfaction? 3) How do these experience factors affect attachment or the feeling of a sense of community? 4) How does attachment or a sense of community play a role in the relationship between experience factors and satisfaction?

\section{Theoretical Background}

\subsection{Experience and the Term 'Experience Economy'}

The concept of 'experience' has received considerable attention from many researchers in recent times (Chang, 2018; Hwang \& Lyu, 2015; Tom Deck, Jung, \& Rauchnabel, 2018). Experience can be defined as a collection of events and activities from which an individual or group may gather knowledge, opinions and skills in a dictionary sense. Knutson and Beck (2003) defined experience as something that individuals with various characteristics gain from emotional, physical, intellectual or spiritual activities on the subject.

Various studies have been conducted on the customer experience, and among these works, it is important to analyze the term 'Experience Economy'. Pine and Gilmore (1998) argued that it was first used in the article 'Welcome to the Experience Economy', and that business should give their customers a valuable experience, and that the experience itself is a commodity. Although the concept of the experience economy was initially focused on business administration, it has crossed into a variety of academic approaches such as hospitality, tourism, sports, IT and others (Chang, 2018; Hwang \& Lyu, 2015; Loureiro, 2014; Oh, Fiore, \& Jeoung, 2007; Tom Deck, Jung, \& Rauchnabel, 2018). According to the experience economy theory, the elements that make up the experience are divided into entertainment, education, escapism and esthetic experiences, depending on the type of consumer participation and interaction with the environment (Pine \& Gilmore, 1998).

The dimensions of customers' experiences have been validated and widely adopted from many studies. As a case in point, Oh et al. (2007) developed a scale that was developed based on the four experiential domains of the experience economy suggested by Pine and Gilmore to explain experiential components in the case of $\mathrm{B}$ \& $\mathrm{B}$ customers in the hospitality business. Experience factors, concepts, and details can be found below.

Education as an experience factor is the desire to learn something new (Pine \& Gilmore, 1998). Consumers will improve their knowledge and skills through active educational experiences of mind and body, and will need to actively participate in 'spirit' for education and 'body' for activities (Pine \& Gilmore, 1998). Many sporting events provide this experience. For example, tourists attending the 
Wimbledon Championship can learn techniques while being close to professional players. In addition, they can acquire knowledge about the rules of tennis and tennis etiquette (Hwang \& Lyu, 2015).

The concept of entertainment in the experience economy is defined as the action of providing or being provided with amusement or enjoyment. For instance, people enjoy watching spectacular plays in an NBA game as observers instead of joining the game as participants (Hwang \& Lyu, 2015). Tourism studies have also supported the importance of entertainment. They found that entertainment is an important antecedent of satisfaction and behavioral intentions. Qu and Ping (1999) found that entertainment is the key factor affecting tourists' satisfaction in a case study of Hong Kong cruise travel. Hosany and Witham (2010) investigated the relationships among international cruisers' experiences, satisfaction and intention to recommend. They found that entertainment plays an important role in the formation of travelers' satisfaction and word-of-mouth (WOM) intentions.

Escapism is defined as an inclination to escape from routine or reality into fantasy. An escapist experience refers to a much higher level of immersion than the entertainment or educational experience. Qu and Ping (1999) found that the need to 'escape from normal life' was a key factor affecting cruise travelers' satisfaction. Kozak (2002) found that the desire to 'escape from actual reality' was an important factor to motivate people to travel somewhere else. In this background, many previous studies have examined the importance of the escapist experience (Hwang \& Ryu, 2015; Tom Deck, Jung, \& Rauchnabel, 2018). Through the professional sports experience, spectators can realize the pleasure of deviating from a complicated routine in the process of being free and immersed in sports. While watching professional sporting events, indirect experience activities can affect the overall satisfaction.

Esthetics, one of the domains of experience, is defined as consumers' interpretation of the physical environment surrounding them (Hosany \& Witham, 2010). An esthetic experience is appreciated passively while being immersed in an environment (Chang, 2018; Hwang \& Lyu, 2015; Oh et al., 2007). Two empirical studies have also verified the importance of esthetics. Bonn, Joseph-Mathews, Dai, Hayes, and Cave (2007) discovered that the esthetic features of attractions pursued by cultural heritage can work in part as key factors affecting revisit and word-of-mouth intentions. Ryu, Lee, and Kim (2012) found that esthetic factors such as attractive interior design and decoration play an important role in the formation of a restaurant's overall image.

\subsection{Attachment}

'Attachment' refers to the propensity of human beings to make strong affectional bonds to particular others (Bowlby, 1979). Due to being rooted to human-to-human connections, attachment has been extended to a number of fields, such as psychology, sociology, business administration, geography, tourism and sports management.

Place attachment is the most common concept among them. Place attachment is defined as the affective bond of a person to a particular environment (Hidalgo \& Hernandez, 2001); or the extent to which an individual values and identifies with a particular environment setting (Moore \& Graefe, 1994). The concept is mainly used in environmental psychology and urban geography. Due to numerous varying opinions on the definition and components of place attachment, place attachment is multi-dimensional and cannot be explained simply through a cause and effect relationship. In that place attachment is aimed at the community, it is only possible if there is social interaction between residents within the geographical area, unlike individual attachment. The relationship between place and destination loyalty was highlighted as an area of interest in tourism research (Prayag \& Ryan, 2012; Yuksel, Yuksel, \& Bilim, 2010).

Attachment has been an interesting subject of research in sports management, and is often measured by 'venue attachment (attachment to a stadium where a sporting game is held)' and 'community/team attachment'. Because sports play a role in combining spectators and communities, there has been a growing number of studies on the place attachment of spectators at venues for mega sporting events or games.

For example, in classic ice hockey games, Ramshaw and Hinch (2006) argued that sports venues serve as manifestations of sports culture and help spectators maintain their memories and reinforce place identities. Brown and Assaker (2013) found that place attachment was operationalized by including measures of place dependence, place identity, place affect and place symbolism in the study at the London Olympic Games. Brown, Smith, and Assaker (2016) analyzed the hierarchical model of involvement with sport, venue attachment, host city evaluation, and satisfaction on visitation intention based on a sample of 603 people attending the 2012 London Olympic Games. They found that psychological bonds with the venue enhance the event experience and spectators who were involved in the sport reacted more strongly to the venue. Spectators with a high level of attachment visit the stadium more and spend more money on products related to their favorite clubs. In this context, they also show a positive relationship on the team's parent company (Gwinner \& Swanson, 2003). 


\subsection{A Sense of Community}

'Sense of community' has been defined as the thoughts and feelings of being a member of a community and is widely studied in the social science disciplines such as psychology and sociology. Sarason (1974) highlighted that a psychological sense of community is the perception of similarity to others, an acknowledged interdependence with others, a willingness to maintain this interdependence by giving to or doing for others what one expects from them, and the feeling that one is part of a larger dependable and stable structure. Similarly, McMillan and Chavis (1986) defined a sense of community as a feeling that members have of belonging, a feeling that members matter to one another and to the group, and a shared belief that members' needs will be met through their agreements to be together. They formed a theoretical basis for a sense of community, and their instrument has been the most widely utilized. According to the McMillan \& Chavis theory, a sense of community consists of four elements: membership, influence integration, fulfillment of needs and shared emotional connection.

Several studies have been conducted on the role of a sense of community (Chavis \& Wandersman, 1990; Kim \& Cho, 2019). Chavis and Wandersman (1990)'s study explored the relationship between a sense of community and community participation and emphasized community participation as an important indicator of community development. Kim and Cho (2019) highlighted that a sense of community positively influences the public's community participation and leads to positive word-of-mouth interactions regarding their communities.

The community is a place where members live, and the quality of the relationship is important to maintain a lasting relationship. In the service distribution market, the higher the quality of the relationship, the more customers continue to use the store without leaving the store. In general, community trust and satisfaction can be seen as an important component (Kim, Jeong, \& Jung, 2017).

With an increasing focus on social impact in the field of sports management, a study to explain the nature and influence of a sense of community in sport has been attempted. Warner, Kerwin, and Walker (2013) developed a multidimensional scale of Sense of Community in Sport, which consisted of 21 items of 6 factors (Administrative Consideration, Common Interest, Equity in Administrative Decisions, Leadership Opportunities, Social Spaces and Competition). Research shows that sports related events and activities do contribute to a sense of community (Schwarz \& Tait, 2007) and sport business plays an important role in contributing to the social psychological concepts of sense of community (Schwarz, 2009). Sport business plays a role in promoting mutual exchanges among local residents and combining local residents and communities. Considering the nature of a sense of community, local sports activities help to form an active sense of community. It is necessary to clarify how spectators' experiences are supported by the sports club with the local franchise affecting the formation of a sense of community.

\subsection{Satisfaction}

The concept of customer satisfaction was first introduced in the field of marketing, and the definition of customer satisfaction and factors affecting satisfaction have been steadily studied in literature. Researchers have tried to define customer satisfaction and in general they have defined it as a transaction process (Mohamud, 2017).

According to Oliver (1980), satisfaction was said to be a psychological state after experiencing products and services of enterprise with static and continuous emotions. Westbrook and Reilly (1983) defined customer satisfaction as an emotional response to the purchasing experience, and Oliver (1981) defined satisfaction as the emotional response and customer perception of the service provider on the basis of comparing the difference between what they receive as compared to previous expectations. Kotler, Armstrong, and Wong (2000) defined customer satisfaction as a person's feelings of pleasure or disappointment resulting from comparing a product or perceived performance (or outcome) in relation to expectations.

In view of this, many papers investigated satisfaction as an important antecedent to forecast consumers' future behavior (Koo, 2005; Kwon \& Yu, 2014; Lee \& Bea, 2006; Sung, Kim, \& Youn, 2014). In particular, Sung, Kim, and Youn (2014) expressed that a consumer's economic and emotional value had influence upon satisfaction in a consumption values survey. In addition, other researchers argued that customer satisfaction is the key predictor of business profitability, and customer satisfaction is positively correlated with profits and sales (Anderson, Fornell, \& Lehmann, 1994; Bernhardt, Donthu, \& Kennett, 2000). These studies found that customer satisfaction serves as a leading indicator of consumer purchase intentions, loyalty and profitability.

From a variety of perspectives, such as in IT businesses, Tang and Chiang (2010) studied the effect of web-blog users' experience on their continuous use intention and satisfaction, and suggested that experience value has a positive correlation with the behavioral intention and satisfaction for blog use. Guo and Li (2012) found in a network environment study that network interaction affects customer experience value and experience value affects customer satisfaction. Shang, Chen and Kim (2017) studied 
the effect of experiential value on customer satisfaction and WOM under $\mathrm{O} 2 \mathrm{O}$ Commerce, and showed that the higher the customer satisfaction, the greater the positive impact on the spread by word of mouth.

For example, sports related research by Greenwell, Fink, and Pastore (2002) found in the case of the American Hockey League that customer's perceptions of physical facility were associated with customer satisfaction. Theodorakis et al. (2013) argued that service quality had a significant and positive effect on spectator's satisfaction in professional football.

\section{Research Method}

\subsection{Research Model and Hypotheses}

This study adopted Pine and Gilmore (1998)'s approach, and the factors of experience in professional sports were defined as the total set of factors that spectators could experience through watching professional baseball games. Considering the active nature of professional sports among the four factors, the three independent variables were categorized as entertainment, educational and escapism experiences. The reason for excluding the esthetic factor from this category is that esthetics has a strong characteristic of passive factors (Chang, 2018; Hwang \& Lyu, 2015; Oh et al., 2007), and, unlike tourism and management there was a limitation in identifying the significant impact relationship by considering the activity.

Attachment and a sense of community can be used as meaningful variables, because sports play a role in combining spectators and communities. In this research, place attachment is measured by venue attachment. Sports spectating plays an important role in contributing to increase the venue attachment and to the social psychological concepts of sense of community (Brown \& Assaker, 2013; Brown, Smith, \& Assaker, 2016; Schwarz, 2009; Warner, Kerwin, \& Walke, 2013).

Satisfaction is used as the most important dependent variable in this study. Visitors' satisfaction is used as a variable in various studies, including the impact relationship between the sports spectator's emotion, experience value, and the service facility environment and satisfaction (Biscaia et al., 2012; Bodet \& Bernache-Assollant, 2011; Brown, Smith, \& Assaker, 2016; Greenwell, Fink, \& Pastore, 2002; Lambrecht, Kaefer, \& Ramenofsky, 2009, Theodorakis et al., 2013). Thus the following hypotheses can be set up.

\footnotetext{
H1: Spectator's experience has a positive effect on satisfaction.
}

H1-1: Spectator's entertainment experience has a positive effect on satisfaction.

H1-2: Spectator's educational experience has a positive effect on satisfaction.

H1-3: Spectator's escapism experience has a positive effect on satisfaction.

H2: Spectator's experience has a positive effect on venue attachment.

H2-1: Spectator's entertainment experience has a positive effect on venue attachment.

H2-2: Spectator's educational experience has a positive effect on venue attachment.

H2-3: Spectator's escapism experience has a positive effect on venue attachment.

H3: Spectator's experience has a positive effect on sense of community.

H3-1: Spectator's entertainment experience has a positive effect on a sense of community.

H3-2: Spectator's educational experience has a positive effect on a sense of community.

H3-3: Spectator's escapism experience has a positive effect on a sense of community

Furthermore, this study tries to confirm how the spectator's attachment and sense of community are related to satisfaction. Several research papers indicated that place attachment or sense of community influenced satisfaction and behavioral intention (Brown \& Assaker, 2013; Brown, Smith, \& Assaker, 2016; Ramshaw \& Hinch, 2006), Thus the following hypotheses can be set up.

H4-1: A spectator's attachment has a positive effect on satisfaction.

H4-2: A spectator's sense of community has a positive effect on satisfaction.

Finally, attachment and a sense of community can be used as mediators. This ensures that the spectator's attachment and the sense of community have mediated effects on the relationship between the spectator experience and satisfaction of the sport. In a study on the sports industry, Brown, Smith and Assaker (2016) hypothesized an impact relationship among sports, venue attachment, satisfaction, and visit intention, and direct or indirect effects of value attachment were examined through a structural model, and a parametric effect study were verified for sense of community. Thus the following hypotheses can be set up.

H5-1: A spectator's attachment mediates the relationship between experience and satisfaction. 
H5-2: A spectator's sense of community mediates the relationship between experience and satisfaction.

Based on the above review, the proposed model is shown in Figure 1. These research models are presented to investigate the impact of a professional sports spectator's experience focusing on the factors of attachment, a sense of community and customer satisfaction. To achieve the purpose of this study, the hypotheses were established.

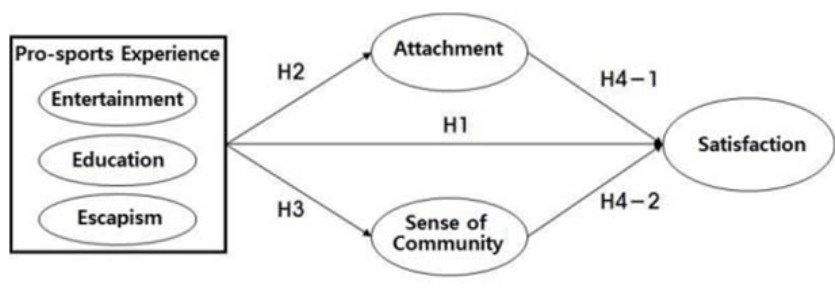

Figure 1: Research Model

This study is to examine the satisfaction of the spectator watching his or her favorite professional baseball game, and also to verify the relationships among attachment, community sense and customer participation according to each experience element. To do this, the research will try to find directions that can increase sports-based local attachment and a sense of community affected by professional sports spectators' active participation, and ultimately lead to the development of local professional sports to further the development of the sports industry.

\subsection{Sample and Data Collection}

The KBO league is the most popular in Korea and a representative sport that adopts the franchise regional tie-up system. The League consists of a total of 10 clubs, but 8 of them are concentrated in Seoul and metropolitan cities, with only 2 teams specialized in sports-oriented cities such as Suwon and Changwon. In this study, home fans at KBO games in 2018 were selected as the population. But due to the efficiency and constraints of the research, the field survey was intended to be limited to a specific urban team. From this point of view, Suwon KT WIZ park was adopted as a sample place for people considering the importance of the sports industry in the city and a representative team with a franchise in a medium-sized city, and not a metropolitan city.

The survey was conducted during a four-day weekend when Suwon KT Wiz's home game was held, during the 2018 professional baseball pennant race. In total, 200 questionnaires were collected at the stadium, but a total of 189 copies were used for the data analysis. 11 surveys could not be used as data due to insincere responses or some missing items. The collected data were analyzed using the SPSS 22.0 statistical package.

\subsection{Measures}

In order to empirically measure the constructs in the proposed model, validated measurement items were adapted from the existing literature and slightly revised to ensure their appropriateness for professional baseball in the sports industry. The derived items were measured on a 5 point Likert-type scale, anchored from strongly disagree (1) to strongly agree (5). In addition, for the basic data of the study, demographic variables were composed of 9 items and measured using nominal scales.

\subsubsection{Measures of Experience}

The spectators' pro-baseball game experience, as it related to entertainment, education, and escapism, was measured using 12 items from Hosany and Witham (2010), Hwang and Lyu (2015), Loureiro (2014), Oh et al. (2007), and tom Dieck, Jung, and Rauchnabel (2018). As for the entertainment, this study use 4 items including the valuation of 'Watching a game was entertaining', 'Watching a game kept me amused', 'Watching a game was fun', and 'Watching a game was really captivating'. And 4 iterms including 'Watching a game was a real learning experience', 'Watching a game made me more knowledgeable', 'Watching a game stimulated my curiosity to learn new things', and 'I learned something new while watching a game' are used to evaluate the educational experience. As for the escapism, 4 iterms including 'I felt I was in a different world while watching a game', 'I completely escaped from my daily routine while watching a game', 'I forgot my daily routine while watching a game', and 'I felt like I was in a different time or place while watching a game' are used.

\subsubsection{Measures of Attachment and a Sense of Community}

Attachment was measured by 4 items adapted from Brown, Smith, and Assaker (2016), Loureiro (2014), and Vada, Prentice, and Hsiaoa (2019). These items include 'I can tell you a lot if someone asks about this venue/place', 'I say I live in this venue/place to explain who I am', 'This venue/place is a big part of my life', and 'I am proud to live in this venue/place'.

As for a sense of community, 4 items including 'I feel connected with others in my community/neighborhood', 'people in my community/neighborhood are good at influencing each other', 'My community/neighborhood helps me fulfill my needs', and 'I can get what I need in my community/neighborhood' were used. These are borrowed from Kim and Cho (2019), Kuo 
and Feng (2013), and Swimberghea, Darratb, Beala, and Astakhova (2018).

\subsubsection{Measures of Satisfaction}

Satisfaction was measured using 3 items adapted from Brady, Voorhees, Cronin, and Bourdeau (2006), Oliver (1980), and Theodorakis et al. (2013). The 3 items include 'Overall, satisfied with my decision to watch a game', 'I did the right thing by watching a game', and 'Happy with my decision to watch a game'.

\section{Results}

\subsection{Demographic Characteristics of Responses}

The frequency analysis of the surveyed ( $N=189)$ was conducted to explain demographic characteristics and was presented in Table 1. Among the participants, 59.3\% $(\mathrm{N}=112)$ reported their gender as male and $40.7 \%(\mathrm{~N}=77)$ as female. This means that watching sports is still more male-oriented than female. 20-29 year olds (55\%, $\mathrm{N}=104)$ and $30-30$ year olds $(16.4 \%, \mathrm{~N}=31)$ accounted for over $70 \%$ of the respondents. Of the 189 respondents, $69.8 \%(\mathrm{~N}=132)$ are single and $30.2 \%(\mathrm{~N}=57)$ are married. In terms of education, 56.1\% ( $\mathrm{N}=106)$ had completed a college degree, 23.3\% ( $\mathrm{N}=44)$ a high school degree. 16.9\% $(\mathrm{N}=32)$ a junior college, and 3.7\% ( $\mathrm{N}=7)$ a master or doctoral degree. $61.4 \%$ $(\mathrm{N}=116)$ were accompanied by friends/lovers, $23.8 \%(\mathrm{~N}=45)$ with family/relatives and $12.7 \%(\mathrm{~N}=24)$ with a group/ organization. This supports the fact that among the respondents, the number of professional baseball spectators is relatively young, and since there are a considerable number of unmarried visitors, there are more spectators with friends than with family.

\subsection{Verification of the Reliability and Validity}

In order to analyze the reliability and validity of the questionnaire measurement factors, Exploratory Factor Analysis (EFA) and Cronbach's $\alpha$ were verified (Choi \& Lee, 2018). Cronbach's $\alpha$ is well known as an internal consistency estimate of the reliability of test scores, For validity, Exploratory Factor Analysis was conducted with the items using principal component analysis extraction and Varimax rotation, determining the number of factors with an eigenvalue of 1.0 or higher.

This study conducted factor analysis on the validity of the professional sports experience. Six factors were extracted as shown in Table 2. These Factors explain $75.898 \%$ of the total variance. The $\mathrm{KMO}$ value was used as a coefficient that verifies the suitability of the sample size, and it was high at 0.872 ( $d f=253$ ). Bartlett's test of sphericity value indicates that the data were sufficient to proceed for the factor analysis, because correlation between variables was statistically significant $(p<.001)$. Measuring variables using this study were applied similarly to those of existing studies. As a result, it was confirmed that values were obtained as indicators of the validity (convergent validity and discriminant validity) and the reliability of variables.

Common Method Bias is an error that may appear in the questionnaire method and arise from the difference between when a survey is conducted and how it is investigated. In general, the results of overall causality verification tend to be good with Common Method Bias (Cho, 2015). Common Method Bias has several methods, but Harman's SingleFactor Test was used and confirmed (Podsakoff, macKenzie, Lee, \& Podsakf, 2003). The results of a Principal Component Analysis on all variables shows that six factors have been extracted, total variances account for $75.90 \%$, and the first of these factors explains $38.23 \%$ of total variances, which means that the deviation of Common Method Bias is not serious in this study.

Table 1: Demographic Characteristics of the Sample (\%, $n=189$, Korea).

\begin{tabular}{|c|c|c|c|c|c|c|c|}
\hline \multirow{2}{*}{ Variable } & \multirow{2}{*}{ Categories } & \multicolumn{2}{|c|}{ Frequency } & \multirow{2}{*}{ Variable } & \multirow{2}{*}{ Categories } & \multicolumn{2}{|c|}{ Frequency } \\
\hline & & $\mathbf{N}$ & Percentage(\%) & & & $\mathbf{N}$ & Percentage(\%) \\
\hline \multirow{2}{*}{ Gender } & Male & 112 & 59.3 & \multirow{2}{*}{$\begin{array}{l}\text { Marital } \\
\text { Status }\end{array}$} & Married & 57 & 30.2 \\
\hline & Female & 77 & 40.7 & & Single & 132 & 69.8 \\
\hline \multirow{8}{*}{ Age } & $<20$ & 16 & 8.5 & \multirow{4}{*}{ Education } & Senior high school & 44 & 23.3 \\
\hline & $20-29$ & 104 & 55.0 & & Junior college & 32 & 16.9 \\
\hline & $30-39$ & 31 & 16.4 & & College degree & 106 & 56.1 \\
\hline & $40-49$ & 16 & 8.5 & & Master/Doctoral degree & 7 & 3.7 \\
\hline & \multirow{2}{*}{$50-59$} & \multirow{2}{*}{16} & \multirow{2}{*}{8.5} & \multirow{4}{*}{$\begin{array}{c}\text { Companion } \\
\text { Status }\end{array}$} & Family/Relatives & 45 & 23.8 \\
\hline & & & & & Friends/Lovers & 116 & 61.4 \\
\hline & \multirow{2}{*}{$>59$} & \multirow{2}{*}{6} & \multirow{2}{*}{3.2} & & Group/Organization & 24 & 12.7 \\
\hline & & & & & No Companion & 4 & 2.1 \\
\hline
\end{tabular}


Table 2: Analysis of the Validity and the Reliability of Variables

\begin{tabular}{|c|c|c|c|c|c|c|c|c|c|}
\hline \multirow{2}{*}{\multicolumn{3}{|c|}{ Factor and Variables }} & \multicolumn{6}{|c|}{ Component } & \multirow{2}{*}{ Cronbach's a } \\
\hline & & & \multirow{2}{*}{\begin{tabular}{c|}
1 \\
.841
\end{tabular}} & 2 & 3 & 4 & \multirow[t]{2}{*}{5} & 6 & \\
\hline \multirow{4}{*}{ Escapism } & \multicolumn{2}{|c|}{ I felt I was in a different world while watching a game } & & & & & & & \multirow{4}{*}{.909} \\
\hline & \multicolumn{2}{|c|}{ I completely escaped from my daily routine while watching a game } & .831 & & & & & & \\
\hline & \multicolumn{2}{|c|}{ I forgot my daily routine while watching a game } & .831 & & & & & & \\
\hline & \multicolumn{2}{|c|}{ I felt like I was in a different time or place while watching a game } & .827 & & & & & & \\
\hline \multirow{4}{*}{ Entertainment } & \multicolumn{2}{|c|}{ Watching a game was entertaining } & & .792 & & & & & \multirow{4}{*}{.884} \\
\hline & \multicolumn{2}{|c|}{ Watching a game kept me amused } & & .764 & & & & & \\
\hline & \multicolumn{2}{|c|}{ Watching a game was fun } & & .746 & & & & & \\
\hline & \multicolumn{2}{|c|}{ Watching a game was really captivating } & & .674 & & & & & \\
\hline \multirow{4}{*}{$\begin{array}{l}\text { Sense } \\
\text { community }\end{array}$} & \multicolumn{2}{|c|}{ I feel connected with others in my community/neighborhood } & & & .870 & & & & \multirow{4}{*}{.867} \\
\hline & \multicolumn{2}{|c|}{$\begin{array}{l}\text { People in my community/neighborhood are good at influencing } \\
\text { each other }\end{array}$} & & & .827 & & & & \\
\hline & \multicolumn{2}{|c|}{ My community/neighborhood helps me fulfill my needs } & & & .772 & & & & \\
\hline & \multicolumn{2}{|c|}{ I can get what I need in my community/neighborhood } & & & .760 & & & & \\
\hline \multirow{4}{*}{ Education } & \multicolumn{2}{|c|}{ Watching a game was a real learning experience } & & & & .754 & & & \multirow{4}{*}{.864} \\
\hline & Watching a gam & re knowledgeable & & & & .743 & & & \\
\hline & Watching a gam & y curiosity to learn new things & & & & .707 & & & \\
\hline & I learned sometr & watching a game & & & & .697 & & & \\
\hline & I can tell you a I & sks about this venue/place. & & & & & .787 & & \\
\hline Attachmont & I say I live in this & o explain who I am. & & & & & .764 & & 708 \\
\hline Allacimnerit & This venue/plac & f my life. & & & & & .731 & & .170 \\
\hline & I am proud to liv & place & & & & & .671 & & \\
\hline & Overall, satisfiec & ion to watch a game & & & & & & .732 & \\
\hline Satisfaction & I did the right thi & a game & & & & & & .703 & .882 \\
\hline & Happy with my c & h a game & & & & & & .663 & \\
\hline $\begin{array}{l}\text { Kaiser-Meyer-Olkin( } \\
\text { of Sampling Adequa }\end{array}$ & $\begin{array}{l}\text { (KMO) Measure } \\
\text { acy (MSA): } 872\end{array}$ & Initial Eigenvalue & 8.793 & 3.300 & 1.726 & 1.458 & 1.120 & 1.060 & $\begin{array}{l}\text { Explained } \\
\text { total } \\
\text { variance } \%\end{array}$ \\
\hline $\begin{array}{l}\text { Bartlett's Test of Spl } \\
\text { significance at } \mathrm{p}=00\end{array}$ & $\begin{array}{l}\text { ohericity } \\
00\end{array}$ & Extracted Variance \% & 38.23 & 14.35 & 7.50 & 6.34 & 4.87 & 4.61 & 75000 \\
\hline & & Rotated Variance \% & 14.66 & 13.59 & 13.48 & 13.06 & 11.40 & 9.70 & \\
\hline
\end{tabular}

\subsection{Hypothesis Verification}

In this study, after exploratory factor analysis and reliability analysis are performed, as statistical techniques of verifying research hypotheses, the hierarchical multiple regression correlation is conducted in order to explore the influence of a spectator's experiences (entertainment/ education/escapism) on attachment, sense of community and customer satisfaction. All variables required for hypothesis testing are converted to potential variables as the average value obtained by summing the measured variables for each factor shown in the exploratory factor analysis.

Typical of the hierarchical multiple regression based analysis is the very frequently cited and widely used procedure described by Baron and Kenny (1986). Hierarchical regression is a way to show if variables of researcher interest explain a statistically significant amount of variance in your Dependent Variable (DV) after accounting for all other variables (Patrick \& Eugene, 2008). Hierarchical regression will be determined by the three-stage regression to determine whether a mediated role is to be performed as 
follows: The analysis results will be shown by the independent variable as a significant effect on the mediation variable in the first equation (i). In the second equation (ii), the independent variable should show significant effects on the dependent variable and in the third equation (iii), the mediation variable appears to have a significant effect on the dependent variable. Finally, for independent variable coefficients, the value of the three-stage regression coefficients shall be less than that of the two-stage regression coefficients. In the three-stage regression analysis, the existence of a mediation effect is determined as follows: when the mediation variable is controlled in regression, if the effects of the independent variable on the dependent variable are not significant, it is considered to be 'complete mediation', and if significant, 'partial mediation'.

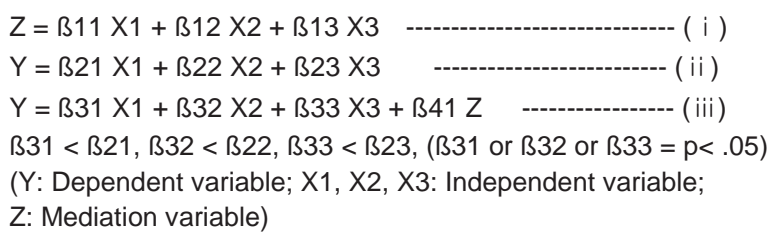

\subsubsection{One-stage Regression Results}

The results of the regression analysis for Hypothesis 2 demonstrate that a spectator's entertainment ( $\mathrm{t}=2.391$, $\mathrm{p}=.018<.05)$ and educational experiences $(\mathrm{t}=2.486$, $\mathrm{p}=.014<.05)$ have a significant effect on attachment, but escapism ( $t=.089, p=.929>.05)$ has no significant impact on attachment. Thus, Hypothesis 2 is adopted in part (entertainment and education). Although entertainment and educational experiences are important factors in the experience economy, escapism is not a factor affecting spectator attachment in this sports case study.

The results of the analysis for Hypothesis 3 show the following: a spectator's educational experience $(t=3.500$, $\mathrm{p}=.001$ ) has a positive effect on sense of community, but entertainment ( $\mathrm{t}=1.099, \mathrm{p}=.273>.05)$ and escapism ( $\mathrm{t}=$ $1.533, p=.127>.05)$ have no significant impact on a sense of community. For Hypothesis 3, whereas education is accepted, entertainment and escapism are overruled. Thus, Hypothesis 3 is accepted partially.

\subsubsection{Two-stage Regression Results}

The results of the regression analysis for Hypothesis 1 demonstrate that a spectator's entertainment ( $\mathrm{t}=3.855$, $\mathrm{p}=.000<.001)$, education $(t=6.227, \mathrm{p}=.000<.001)$ and escapism $(t=2.184, p=.030<.05)$ have a significant effect on satisfaction. The findings show that the experience economy has a significant effect on satisfaction. Thus, Hypothesis 1 is accepted. It has been confirmed that entertainment, education and escapism are key factors for satisfaction, which is the same as other studies (Petrick, Tonner, \& Quinn, 2006; Qu \& Ping, 1999).

The results based on the regression analyses of the above hypothesis 1, 2 and 3 tests is shown in figure 2 .

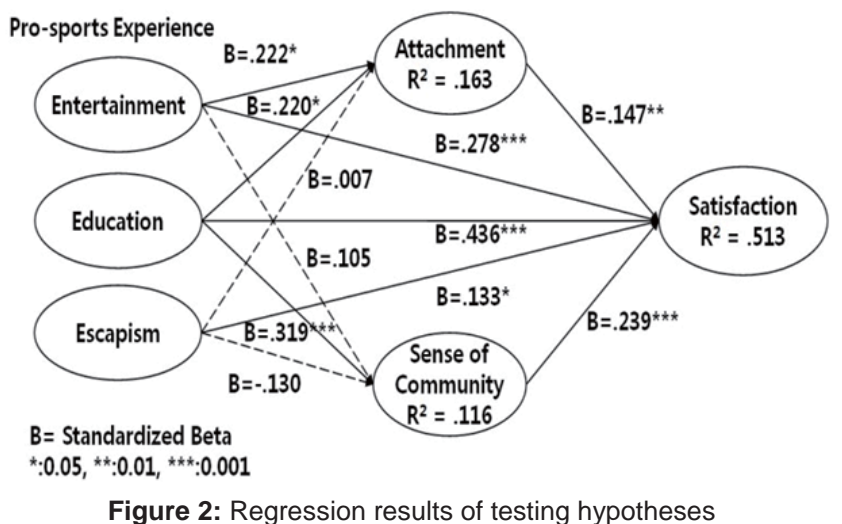

\subsubsection{Three-stage Regression Results}

The results of the analysis for Hypothesis 4-1 and Hypothesis 4-2 show the following. Spectators' attachment has a positive effect on satisfaction $(t=2.634, p=.009<.01)$ and a sense of community also has a positive effect on satisfaction $(t=4.445, p=.000<.001)$. A higher VIF (variance inflation factor) value indicates a higher degree of co-efficiency among independent variables, and the criterion for determining collinearity is whether the VIF value is less than 10 or not. The result was found to be not collinear, with attachment 1.195 and sense of community 1.131. Thus, Hypothesis 4-1 and Hypothesis 4-2 are supported.

\subsubsection{Mediating Effect Results}

According to the comparison of $\beta$ coefficients in 3-stage and 2-stage, regression results, mediation effects of spectators' attachment and a sense of community are as follows: First, for all three factors of experience, the threestage regression coefficients are found to be less than that of the two-stage regression coefficients (e.g. Entertainment: $0.188<0.214$, Education: $0.259<0.280$, Escapism: $0.102<$ $0.103)$. Attachment has a mediating effect in the relationship between spectators' experience factors and satisfaction. 
Table 3: Mediating Effect Verification

\begin{tabular}{|c|c|c|c|c|c|c|c|c|c|c|c|c|c|}
\hline \multirow{3}{*}{ Stage } & \multirow{3}{*}{ Independent Variable } & \multicolumn{6}{|c|}{ Mediation Variable } & \multirow{2}{*}{\multicolumn{6}{|c|}{$\begin{array}{c}\text { Dependent Variable } \\
\text { Satisfaction }\end{array}$}} \\
\hline & & \multicolumn{3}{|c|}{ Attachment } & \multicolumn{3}{|c|}{ Community Sense } & & & & & & \\
\hline & & B & $t$ & VIF & ß & $\mathbf{t}$ & VIF & B & $\mathbf{t}$ & VIF & B & $\mathbf{t}$ & VIF \\
\hline \multirow{3}{*}{1} & $\begin{array}{l}\text { Entertainment Experience } \\
\text { (ß11) }\end{array}$ & .262 & $2.391^{*}$ & 1.912 & .162 & 1.099 & 1.912 & & & & & & \\
\hline & $\begin{array}{l}\text { Educational Experience } \\
\text { (B12) }\end{array}$ & .222 & $2.486^{\star}$ & 1.735 & .418 & $3.500 * \star *$ & 1.735 & & & & & & \\
\hline & Escapism Experience (ß13) & .008 & .089 & 1.512 & -.191 & -1.533 & 1.512 & & & & & & \\
\hline \multirow{3}{*}{$\begin{array}{l}2 \\
\text { Stage }\end{array}$} & $\begin{array}{l}\text { Entertainment Experience } \\
(ß 21)\end{array}$ & & & & & & & .214 & $3.855^{\star \star \star}$ & 1.912 & \multirow{3}{*}{\multicolumn{3}{|c|}{$\begin{array}{c}\mathrm{R}^{2}=.513 \\
\mathrm{~F}=65.075^{\star \star} \\
<\mathrm{H} 1>\text { adopted }\end{array}$}} \\
\hline & $\begin{array}{l}\text { Educational Experience } \\
\text { (B22) }\end{array}$ & & & & & & & .280 & $6.227^{\star \star \star}$ & 1.735 & & & \\
\hline & Escapism Experience (ß23) & & & & & & & .103 & 2.184 * & 1.512 & & & \\
\hline \multirow{5}{*}{$\begin{array}{l}3 \\
\text { Stage }\end{array}$} & $\begin{array}{l}\text { Entertainment Experience } \\
\text { (ß31) }\end{array}$ & \multicolumn{3}{|c|}{ B31 < ß21 S } & \multicolumn{3}{|c|}{ B31 < ß21 S } & .188 & $3.401^{\star \star \star}$ & 1.971 & .195 & $3.674^{\star \star \star}$ & 1.925 \\
\hline & $\begin{array}{l}\text { Educational Experience } \\
\text { (B32) }\end{array}$ & \multicolumn{3}{|c|}{$B 32<ß 22 \mathrm{~S}$} & \multicolumn{3}{|c|}{$ß 32<ß 22 \mathrm{~S}$} & .259 & $5.749 * * \star$ & 1.793 & .231 & $5.221^{* * *}$ & 1.850 \\
\hline & Escapism Experience (ß33) & \multicolumn{3}{|c|}{ ß33<ß23 S } & \multicolumn{3}{|c|}{ ß33 > ß23 NS } & .102 & $2.202^{\star}$ & 1.512 & .125 & $2.776^{\star \star}$ & 1.531 \\
\hline & Attachment & & & & & & & .096 & $2.634^{\star *}$ & 1.195 & & & \\
\hline & Sense of Community & & & & & & & & & & .117 & $4.445^{\star \star \star}$ & 1.131 \\
\hline \multicolumn{2}{|c|}{ Model Summary } & \multicolumn{3}{|c|}{$\begin{array}{c}\mathrm{R}^{2}=.163 \\
\mathrm{~F}=12.013^{\star \star \star}\end{array}$} & \multicolumn{3}{|c|}{$\begin{array}{c}\mathrm{R}^{2}=.116 \\
\mathrm{~F}=8.104^{\star \star \star}\end{array}$} & \multicolumn{3}{|c|}{$\begin{array}{c}R^{2}=.531 \\
F=52.106^{\star \star \star}\end{array}$} & \multicolumn{3}{|c|}{$\begin{array}{c}\mathrm{R}^{2}=.561 \\
\mathrm{~F}=58.696^{\star \star \star}\end{array}$} \\
\hline \multicolumn{2}{|c|}{ Model Summary } & \multicolumn{3}{|c|}{$<\mathrm{H} 2>$ adopted Partially } & \multicolumn{3}{|c|}{$<\mathrm{H} 3>$ adopted Partially } & \multicolumn{3}{|c|}{$<\mathrm{H} 4-1>$ adopted } & \multicolumn{3}{|c|}{$<\mathrm{H} 4-2>$ adopted Partially } \\
\hline
\end{tabular}

Second, for two factors of experience, the three-stage regression coefficients are found to be less than that of the two-stage regression coefficients (e.g. Entertainment: $0.195<0.214$, Education: $0.231<0.280$ ). But for one factor of experience, the three-stage regression coefficients are found to be bigger than that of the two-stage regression coefficients (Escapism: 0.125> 0.103). The finding confirms that the mediated effects have been identified for entertainment and educational experiences, and a sense of community has a mediating effect in the relationship between spectators' experience factors and satisfaction. Thus, Hypothesis 5-1 is accepted and Hypothesis 5-2 is accepted partially. In the case of attachment, it reflects that spectators are well aware of the place information and indicates that there is a mediating effect of attachment that affects satisfaction as professional sports spectators have 3 factors of experiences. But in the case of a sense of community, spectators may be restricted by their nature to enjoy deviations from the region, although they are engaged in official or informal activities within the area. The results show that there is a mediating effect of a sense of community when spectators have entertainment and educational experiences, but there is no mediating effect when escapism experience.

\section{Conclusions and Limitations}

\subsection{Conclusion}

The purpose of this study is to investigate the relationships among experience factors, attachment, a sense of community. and customer satisfaction for spectators who have watched professional baseball games. The study focused on the 2018 KBO League, which has become the most popular sport in Korea among many other professional sports. The reason for the research is that in $\mathrm{KBO}$ league games, spectators who come to the stadium to cheer for their favorite clubs are showing continued interest, and enthusiastic attitudes. In addition, KBO clubs show the importance of a city's self-sufficiency and the need for sports franchises in the era of localization. For this purpose, the survey was given to the home fans at Suwon Stadium because this is representative of a team in a medium-sized city. The findings of this paper are summarized as follows.

First, the entertainment, educational and escapism experiences of spectators have a significant impact on satisfaction. Since their experiences have strong educational and empirical factors, such as unknown interests and understanding of the rules of baseball, it is important for the club to improve customer satisfaction, and to pay attention to 
providing suitable fan services and maintaining the physical environment (McEvoy et al., 2005; Shin \& Lyu, 2018).

Second, the entertainment and educational experiences of the spectators were shown to have a significant effect on attachment. However, escapism did not have a significant effect on attachment. It was found that escapism does not have a significant effect on attachment because unlike tourism or travel, spectators' participation in a game takes place near their residential areas rather than by traveling long distances. This shows a strong connection with the local environment in the city rather than with the external environment. Some of the findings are similar to those of previous studies (Louireiro, 2014; Vada, Prentice, \& Hsiao, 2019).

Third, it has been shown that the educational experience of the spectators has a significant effect on a sense of community, and that entertainment and escapism experiences do not significantly affect a sense of community. The crowd, through watching professional sports can get educational opportunities to improve their sports related knowledge and skills. These educational experiences can enhance this feeling of a sense of community (Kim \& Cho, 2019; Kim, Jeong, \& Jung, 2017; McMillan \& Chavis, 1986).

Fourth, the attachment of spectators has been shown to have a significant impact on satisfaction. And the sense of community has a significant impact on satisfaction. This result is the same as that of previous research on the relationship between place attachment and satisfaction (Brown \& Assaker, 2013; Prayag \& Ryan, 2012; Yuksel, Yuksel, \& Bilim, 2010).

Fifth, it has been shown that attachment has all the mediated effects on entertainment, education, escapism, and satisfaction for professional sports. Furthermore, it turns out that a sense of community has a mediated effect on entertainment, educational experiences, and satisfaction for professional sports.

The findings have shown that attachment and a sense of community are meaningful mediating variables in the relationship between experience and satisfaction. Attachment can involve concepts such as venue attachment to a stadium or team attachment, so all KBO clubs need to pay constant attention to the stadium so that it can establish itself as a franchise city's landmark. A sense of community can lead to community immersion that creates a bond between KBO clubs and spectators. This can increase satisfaction and serve as an important key in expanding customer demand and boosting the Korean professional sports distribution market.

\subsection{Limitations}

Limitations of this study need to be addressed. They are summarized as follows.
First, the surveys were given to spectators of one specific KBO team, which means that the results can be difficult to generalize. Future studies should use larger samples, including the spectators of other KBO teams, to allow the results to be generalized with more confidence.

Second, professional sports-related tourism research has been conducted using a diverse approach for popular spectator sports in the United States and Western Europe. However, the findings of this paper may be limited because this survey has covered the KBO market only. The reason for this is that the sports management and distribution systems in North America and Europe, as well as the needs and expectations of spectators, are different from those formed in the Korean markets. Subsequently, cross-cultural studies should be conducted in the future, to highlight the similarities and differences across countries and continents.

Third, as already mentioned, experience, attachment, a sense of community and satisfaction are four constructs used in this study. However, there are other important variables which can be expected to help effectively explain the relationship factors that affect a customer's satisfaction. They were not included in the study. Examples are perceived value (Zeithaml, 1988), physical sports facilities and sportscapes (Greenwell, Fink, \& Passtore, 2002; Shin \& Lyu, 2018), fan motives (Wang, Zhang, \& Tsuji, 2011) and service quality (Giao, 2019; Kim \& Shim, 2019; Mohamud, 2017; Theodorakis et al., 2013).

Finally, more consequences of experience and satisfaction should be investigated in future studies. It is also necessary to use all four factors that belong to the experience economy by Pine and Gilmore (1998) as independent variables to verify if they have an impact on other variables. Because of its inherent nature, the esthetic factor was excluded from the study. This study used customer satisfaction, but in future studies, behavioral intention or loyalty may be applied as a dependent variable that has been used by a majority of the previous studies.

\section{References}

Anderson, E. W., Fornell, C., \& Lehmann, D. (1994). Customer Satisfaction, Market Share, and Profitability: Findings from Sweden. Journal of Marketing, 58(3), 53-66. DOI: $10.2307 / 1252310$

Baron, R., \& Kenny, D. (1986). The moderator-mediator variable distinction in social psychological research: Conceptual, strategic, and statistical considerations. Journal of Personality and Social Psychology, 51, 11731182.

Bernhardt, K. L., Donthu, N., \& Kennett, P. A. (2000). A Longitudinal Analysis of Satisfaction and Profitability/ 
Journal of Business Research, 47(2), 161-171. https://doi.org/10.1016/S0148-2963(98)00042-3

Biscaia, R., Correia, A., Rosado, A., Maroco, J., \& Ross, S. (2012). The effects of emotions on football spectators' satisfaction and behavioural intentions. European Sport Management Quarterly, 12(3), 227-242. https://doi.org/10.1080/16184742.2012.679949

Bodet, G., \& Bernache-Assollant, I. (2011). Consumer loyalty in sport spectatorship services: The relationships with consumer satisfaction and team identification. Psychology \& Marketing, 28(8), 781-802. https://doi.org/10.1002/mar.20412

Bonn, M. A., Joseph-Mathews, S. M., Dai, M., Hayes, S., \& Cave, J. (2007). Heritage/cultural attraction atmospherics: creating the right environment for the heritage/cultural visitor. Journal of Travel Research, 45(3), 345354.https://doi.org/10.1177/0047287506295947

Bowlby, J. (1979). The Making $d$ breaking of affectional bonds. London, England: Tavistok.

Brady, M. K., Voorhees, J. J., Cronin, J. Jr., \& Bourdeau, B. L. (2006). The good guys don't always win: The effect of valence on service perceptions and consequences. Journal of Services Marketing, 20(2), 83-91.

Brown, G., \& Assaker, G. (2013). Exploring place attachment: An empirical analysis of sports events spectators. Proceedings of the CAUTHE annual conference (pp.11-14). Lincoln, England: University of Lincoln.

Brown, G., Smith, A., \& Assaker, G. (2016). Revisiting the host city: An empirical examination of sport involvement, place attachment, event satisfaction and spectator intentions at the London Olympics. Tourism Management, 55 , 160-172. http://dx.doi.org/10.1016/j.tourman.2016.02.010

Chang, S. H. (2018). Experience economy in hospitality and tourism: Gain and loss values for service and experience". Tourism Management, 64(C), 55-63. https://doi.org/10.1016/j.tourman.2017.08.004

Chavis, D. M., Hogge, J. H., McMillan, D. W., \& Wandersman, A. (1986). Sense of community through Brunswick's lens: A first look. Journal of Community Psychology, 14(1), 24-40.

Chavis, D. M., \& Wandersman, A. (1990). Sense of community in the urban environment: A catalyst for participation and community development. American Journal of Community Psychology, 18(1), 55-81. https://doi.org/10.1007/BF00922689

Cho, Y. S. (2015). The Role of Relational Capital in Supply Chain Management for Distribution Service Firms. Journal of Distribution Science, 13(11), 111-121. http://dx.doi.org/10.15722/jds.13.11.201511.111
Choi, H. Y., \& Lee, H. J. (2018). A Study on Moment of Truth of Household Telecommunication and Distribution Services in Korea. Journal of Distribution Science, 16(6), 37-53. http://dx.doi.org/10.15722/jds.16.6.201806.37

Giao, H. N. (2019). Customer Satisfaction towards ATM Services: A Case of Vietcombank Vinh Long, Vietnam. Journal of Asian Finance, Economics and Business, 6(1), 141-148. http://doi.org/10.13106/jafeb.2019.vol6.no1.141

Greenwell, T. C., Fink, J. S., \& Pastore, D. L. (2002). Assessing the Influence of the Physical Sports Facility on Customer Satisfaction within the Context of the Service Experience. Sport Management Review, 5(2), 129-148. https://doi.org/10.1016/S1441-3523(02)70064-8

Guo, G. Q., \& Li, G. M. (2012). The influence of interactivity of online shopping on consumers' experiential value and satisfaction. China Business and Market, 2, 112-118.

Gwinner, K., \& Swanson, S. (2003). A model of fan identification: antecedents and sponsorship outcomes. Journal of Services Marketing, 17(3), 275-294. https://doi.org/10.1108/08876040310474828

Hidalgo, M. C., \& Hernandez, B. (2001). Place attachment: conceptual and empirical questions. Journal of Environmental Psychology, 21(3), 273-281. https://doi.org/10.1006/jevp.2001.0221

Hosany, S., \& Witham, M. (2010). Dimensions of cruisers' experiences, satisfaction, and intention to recommend. Journal of Travel Research, 49(3), 351-364. https://doi.org/10.1177/0047287509346859

Hwang, J. D., \& Lyu, S. O. (2015). The antecedents and consequences of well-being perception: An application of the experience economy to golf tournament tourists. Journal of Destination Marketing \& Management, 4(4), 248-257. http://dx.doi.org/10.1016/j.jdmm.2015.09.002

Kim, C. H., Jeong, S. O., \& Jung, Y. S. (2017). A Study on the Effect of Social Value of Traditional Market on Satisfaction, Loyalty and Local Attachment, Journal of Distribution Science, 15(2), 59-68. http://dx.doi.org/10.15722/jds.15.2.201702.59

Kim, H. S., \& Shim, J. H. (2019). The Effects of Quality Factors on Customer Satisfaction, Trust and Behavioral Intention in Chicken Restaurants. International Journal of Industrial Distribution \& Business, 10(4), 43-56. http://dx.doi.org/10.13106/ijidb.2019.vol10.no4.43.

Kim, M. S., \& Cho, M. H. (2019). Examining the role of sense of community: Linking local government public relationships and community-building. Public Relations Review, 45(2), 297-306. https://doi.org/10.1016/j.pubrev.2019.02.002

Knutson, B. J., \& Beck, J. A. (2003), Identifying the dimensions of the experience construct: Development of the model. Journal of Quality Assurance in Hospitality and 
Tourism,

$4(3 / 4)$,

23-35. https://doi.org/10.1300/J150v15n03_03

Koo, Y. D. (2005). The Effect of the Perception on the Physical Environment in Discount Stores on Customer Satisfaction and Intention. Journal of Distribution Science, 3(2), 29-56.

Kotler, P., Armstrong, J., \& Wong, V. (2000). Principle of Marketing (2nd European Edition). London, England: Prentice-Hall.

Kozak, M. (2002). Comparative analysis of tourist motivations by nationality and destinations. Tourism Management, 23(3), 221-232. https://doi.org/10.1016/S0261-5177(01)00090-5

Kuo, Y. F., \& Feng, L. H. (2013). Relationships among community interaction characteristics, perceived benefits, community commitment, and oppositional brand loyalty in online brand communities. International Journal of Information Management, 33, 948-962. https://doi.org/10.1016/j.ijinfomgt.2013.08.005

Kwon, Y. D., \& Yu, J. P (2014). Effects of the Support and Control of Franchisors on Franchisees' Satisfaction and Response Strategies. Journal of Distribution Science, 12(8), 43-54.

Lambrecht, K. W., Kaefer, F., \& Ramenofsky, S. D. (2009). Sportscape factors influencing spectator attendance and satisfaction at a professional golf association tournament. Sport Marketing Quarterly, 18(3), 165-172.

Lee, J. G., \& Bea, M. E. (2006). The Impact of Interpersonal Relationships on Department Stores Customer Satisfaction and Trust, Loyalty. Journal of Distribution Science, 4(1), 27-52

Lee, Y. H. (2006). The decline of attendance in the Korean Professional Baseball League: The major league effects. Journal of Sports Economics, 7(2), 187-200. https://doi.org/10.1177/1527002504271355

Loureiro, S. M. (2014). The role of the rural tourism experience economy in place attachment and behavioral intentions. International Journal of Hospitality Management, $\quad 40, \quad 1-9$. https://doi.org/10.1016/j.ijhm.2014.02.010

McEvoy, C. D., Nagel. M. S., DeSchriver, T. D., \& Brown, M. T. (2005). Facility Age and Attendance in Major League Baseball. Sport Management Review, 8, 19-41.

McMillan, D. \& Chavis, D. (1986). Sense of community: A definition and theory. Journal of Community Psychology, 14, 6-23. https://doi.org/10.1002/1520-6629(198601)14:1 $<6:: A I D-J C O P 2290140103>3.0 . C O ; 2-I$

Mohamud, J. A. (2017). The Interrelationship between Service Quality, Electronic Banking and Customer Satisfaction in the Commercial Banks in Uganda. East Asian Journal of Business Economics, 5(1), 27-32. http://dx.doi.org/10.20498/eajbe.2017.5.1.27
Moore, R. L., \& Graefe, A. R. (1994). Attachments to recreation settings: The case of rail-trail users. Leisure Sciences, 16, 17-31. https://doi.org/10.1080/01490409409513214

Moreno, F. C., Prado-Gascó, V., Hervas, J., C., NúñezPomar, J., \& Sanz, V. A., (2015). Spectator emotions: Effects on quality, satisfaction, value, and future intentions. Journal of Business Research, 68, 1445-1449. http://dx.doi.org/10.1016/j.jbusres.2015.01.031

Oh, H., Fiore, A. M., \& Jeoung, M. (2007). Measuring experience economy concepts: tourism applications. Journal of Travel Research, 46, 119-132. https://doi.org/10.1177/0047287507304039

Oliver, R. L. (1980). Cognitive Model of the Antecedents and Consequences of Satisfaction Decisions. Journal of Marketing Research, 17, 460-469. https://doi.org/10.1177/002224378001700405

Oliver, R. L. (1981). Measurement and Evaluation of Satisfaction Processes in Retail Settings, Journal of Retailing, 57, 25-48.

Patrick J. R., \& Eugene, F. (2008). Problems with detecting assumed ediation using the hierarchical multiple regression strategy. Human Resource Management Review, 18(4), 294-310. https://doi.org/10.1016/j.hrmr.2008.07.009

Petrick, J., Tonner, C., \& Quinn, C. (2006). The utilization of critical incident technique to examine cruise passengers' repurchase intentions. Journal of Travel Research, 44(3), 273-280. https://doi.org/10.1177/0047287505282944.

Pine, B. J. II., \& Gilmore, J. H. (1998), Welcome to the experience economy. Harvard Business Review, 76(4), 97-105.

Podsakoff, P. M., MacKenzie, S. B., Lee, J. Y., \& Podsakoff, N. P. (2003). Common method biases in behavioral research: A critical review of the literature and recommended remedies. Journal of Applied Psychology, 88(5), 879-903.

Prayag, G., \& Ryan, C. (2012). Antecedents of tourists' loyalty to Mauritius: the role and influence of destination image, place attachment, personal involvement and satisfaction. Journal of Travel Research, 51(3), 342-356. https://doi.org/10.1177/0047287511410321

Qu, H. \& Ping, E. W. Y. (1999). A service performance model of Hong Kong cruise travelers' motivation factors and satisfaction. Tourism Management, 20(2), 237-244. https://doi.org/10.1016/S0261-5177(98)00073-9

Ramshaw, G., \& Hinch, T. (2006). Place identity and sport tourism: the case of the heritage classic ice hockey event. Current Issues in Tourism, 9(4\&5), 399-418. https://doi.org/10.2167/cit270.0

Ryu, K., Lee, H. R., \& Kim, W.G. (2012). The influence of the quality of the physical environment, food, and service 
on restaurant image, customer perceived value, customer satisfaction, and behavioral intentions. International Journal of Contemporary Hospitality Management, 24(2), 200-223. https://doi.org/10.1108/09596111211206141

Sarason, S. B. (1974). The psychological sense of community: Prospects for a community psychology. San Francisco, CA: Jossey-Bass.

Schwarz, E. C. (2009). Building a sense of community through sport programming and special events: The role of sport marketing in contributing to social capital. International Journal of Entrepreneurship and Small Business, 7(4), 478-487, https://doi.org/10.1504/IJESB.2009.023364

Schwarz, E. C., \& Tait, R. (2007) 'Recreation, arts, events and festivals: their contribution to a sense of community. Rural Society, 17(2), 125-138.

Shang, Y., Chen, Y., \& Kim, H. S. (2017). Effect of Experiential Value on Customer Satisfaction and e-WOM under $\mathrm{O} 2 \mathrm{O}$ Commerce. Journal of Distribution Science, 15(8), 75-86. http://dx.doi.org/10.15722/jds.15.8.201708.75

Shin, J. H., \& Lyu, S. O. (2018). Using a discrete choice experiment to estimate spectators' willingness to pay for professional baseball park sportscape. Sport Management Review. https://doi.org/10.1016/j.smr.2018.06.009

Sung, H. Y., Kim, J. J., \& Youn, M. K., (2014). A Study upon Effects of Family Restaurant Consumption Values upon Satisfaction, Reliability and Behavioural Intentions in Korea: Focused on College Students at Metropolitan Area. Journal of Asian Finance, Economics and Business, 1(4), 29-37. https://doi.org/10.13106/jafeb.2014.vol1.no4.29

Sutton, W. A., McDonald, M. A., \& Miline, G. R. (1997). Creating and fostering fan identification in professional sports. Sport Marketing Quarterly, 6, 15-22.

Swimberghea, K., Darratb, M. A., Beala, B. D., \& Astakhova, M. (2018). Examining a psychological sense of brand community in elderly consumers. Journal of Business Research, 82, 171-178. https://doi.org/10.1016/j.jbusres.2017.09.035
Tang, J. T. E., \& Chiang, C. H. (2010). Integrating experiential value of blog use into the expectationconfirmation theory model. Social Behavior and Personality: An international journal, 38(10), 1377-1389. DOI: https://doi.org/10.2224/sbp.2010.38.10.1377

Theodorakis, N. D., Alexandris, K., Tsigilis,, N., \& Karvounis, S. (2013). Predicting spectators' behavioural intentions in professional football: The role of satisfaction and service quality. Sport Management Review, 16, 85-96. https://doi.org/10.1016/j.smr.2012.05.004

Tom Dieck, M. C., Jung, Timothy, H. S, \& Rauchnabel, P. A. (2018). Determining visitor engagement through augmented reality at science festivals: An experience economy perspective. Computers in Human Behavior, 82, 44-53. https://doi.org/10.1016/j.chb.2017.12.043

Vada, S., Prentice, C., \& Hsiaoa, A. (2019). The influence of tourism experience and well-being on place attachment, Journal of Retailing and Consumer Services, 47, 333-330. https://doi.org/10.1016/j.jretconser.2018.12.007

Wang, R. T., Zhang, J. J., \& Tsuji, Y. (2011). Examining fan motives and loyalty for the Chinese Professional Baseball League of Taiwan. Sport Management Review, 14, 347360. https://doi.org/10.1016/j.smr.2010.12.001

Warner, S., Kerwin, S., \& Walker, M. (2013). Examining Sense of Community in Sport: Developing the Multidimensional 'SCS' Scale. Journal of Sport Management, 27, 349-362.

Westbrook, R. A., \& Reilly, M. D. (1983). Value-Percept Disparity: An Alternative to the Disconfirmation of Expectations Theory of Consumer Satisfaction. Advances in Consumer Research, 10, 256-261.

Yuksel, A., Yuksel, F., \& Bilim, Y. (2010). "Destination attachment: effects on customer satisfaction and cognitive, affective and conative loyalty". Tourism Management, 31(2), 274-284. https://doi.org/10.1016/j.tourman.2009.03.007

Zeithaml, V. A. (1988). Consumer Perceptions of Price, Quality, and Value: A Means-End Model and Synthesis of Evidence. Journal of Marketing, 52(3), 2-22. https://doi.org/10.1177/002224298805200302 